\title{
Incidence of Dengue Hemorrhagic Fever Related to Annual Rainfall, Population Density, Larval Free Index and Prevention Program in Bandung 2008 to 2011
}

\author{
Anggia Karina, ${ }^{1}$ Sri Yusnita Irda Sari, ${ }^{2}$ H. Uun Sumardi, ${ }^{3}$ Elsa Pudji Setiawati ${ }^{2}$ \\ ${ }^{1}$ Faculty of Medicine Universitas Padjadjaran, ${ }^{2}$ Department of Public Health Faculty of Medicine \\ Universitas Padjadjaran, ${ }^{3}$ Department of of Internal Medicine Faculty of Medicine Universitas \\ Padjadjaran/Dr. Hasan Sadikin General Hospital Bandung
}

\begin{abstract}
Background: Dengue Hemorrhagic Fever (DHF) remains one of health problems in all provinces in Indonesia including West Java. Bandung as the capital of West Java province has dengue prevalence that is above the average prevalence of all provinces. This study aimed to describe the pattern of dengue incidence rate, annual rainfall, population density, and larval free index as well as the implementation of prevention program in sub-districts with the highest incidence rate in Bandung between 2008 and 2011.

Methods: A descriptive retrospective study was conducted in September 2012 using secondary data during the period of January 2008 to December 2011. The incidence rate was calculated based on DHF patients who live in Bandung. Data were analyzed using computer and Arc View 3.3. Pattern of incidence rate was characterized with red, yellow, and green region respectively.

Results: The highest incidence rate of DHF occurred in 2009. Incidence increased in January to February and declined in the end of the year. Subdistricts with highest incidence had no highest annual rainfall and the population density below the average of population density in Bandung. The highest implementation of fogging program was not only performed in high incidence subdistricts but also in area with larval free index less than 95\%. Larval free index in subdistricts with highest incidence were not all below 95\%.

Conclusions: Incidence of DHF increases after months of highly rainfall. The pattern of incidence rate in all subdistrict is dynamic and suspected do not related to annual rainfall, population density, high larva free index, and frequency of fogging. [AMJ.2015;2(1):262-7]
\end{abstract}

Key words: Dengue hemorrhagic fever, fogging, incidence, population density, rainfall.

\section{Introductions}

Dengue Hemorrhagic Fever (DHF) is one of public health issues that becomes an international health problem. The spread of dengue has greatly increased since the last 30 years. ${ }^{1}$ Back in 1970, it was only nine countries which reported dengue case. Currently, it was estimated that arround 100 countries in tropical and subtropical climate known as endemic areas. Approximately, $40 \%$ of the world's population are at risk for dengue virus. From the total population in Southeast Asia, $87 \%$ are at risk of dengue..$^{2,3}$

Indonesia is a country in Southeast Asia included in dengue endemic areas. In 2006, Indonesia had the highest incidence of DHF in Southeast Asia.4 Since first discovered in 1968 in Surabaya, DHF cases in Indonesia have been increasing. Nowadays, all provinces in
Indonesia have reported dengue cases. Based on the reports of the Indonesian Ministry of Health in 2009, it was noted that West Java Province was region with the highest number of dengue cases. $^{5}$ Basic Health Research Survey in West Java province in 2007 showed the prevalence of dengue in Bandung, which is the capital of West Java province, was above the average prevalence of all provinces. ${ }^{6}$

Several factors which affect the increase and spread of dengue cases are high rate of population growth, unplanned and uncontrolled urbanization and lack of effective vector control in endemic areas. Morbidity and mortality from viral infection are also influenced by other factors such as host immunity, density of vector mosquitoes, dengue virus virulency and local geographical conditions. Pattern outbreak of dengue virus infection is also influenced by climate and

Correspondence: Anggia Karina, Faculty of Medicine, Universitas Padjadjaran, Jalan Raya Bandung-Sumedang Km.21, Jatinangor, Sumedang, Indonesia, Phone: +6282116826465 Email: anggia.karina@yahoo.com 


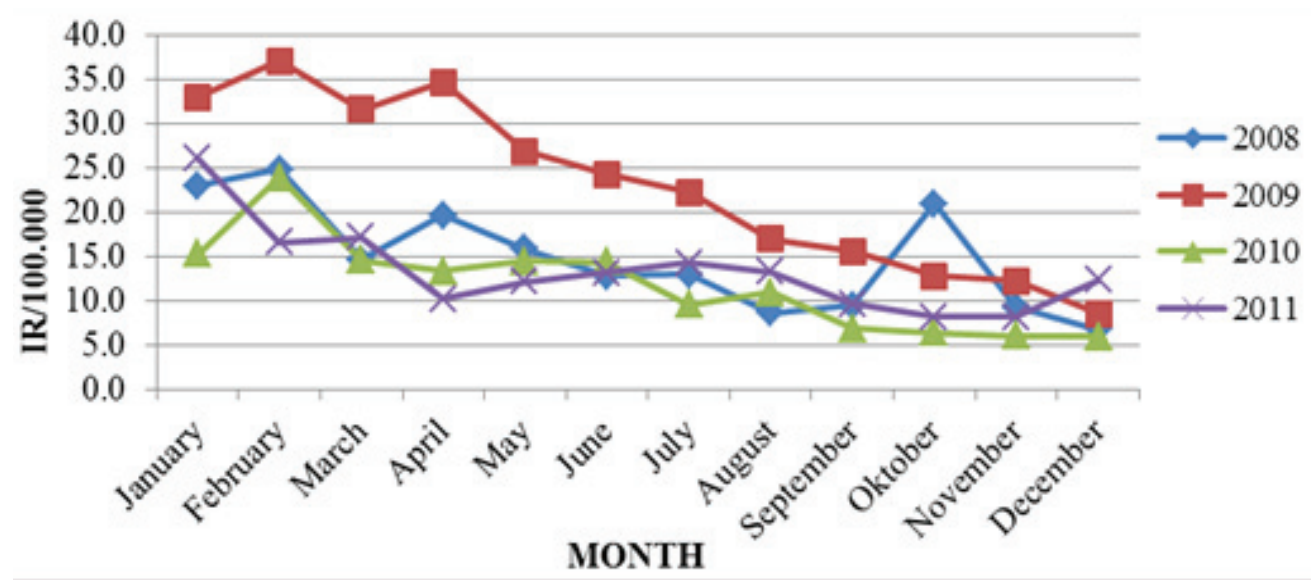

Figure 1 DHF Incidence Monthly in Bandung during the Period of 2008 to 2011

humidity, where the hot temperatures (2832 degree Celcius) and high humidity is an intermediate vector of dengue virus in order to stay alive. ${ }^{5}$ Climatic factors and population density in Bandung might affect the presence of mosquito as the vector for dengue transmission. ${ }^{6}$ The incidence of DHF patients is estimated to increase especially after flood and climatic changes. This leads to a large number of water shelters as puddles, in bottles, cans and other water reservoir which are close to settlement. ${ }^{5}$ This kind of fresh water shelters are good place for dengue vector breeding. ${ }^{7}$

This study aimed to describe the pattern of dengue incidence rate, average rainfall, and population density, as well as the implementation of prevention program in subdistricts with the highest incidence rate in Bandung between 2008 and 2011.

\section{Methods}

A descriptive retrospective study was conducted using secondary data which were obtained from Bandung Health Office and Health Research Unit in Faculty of Medicine, Universitas Padjadjaran. Data of DHF patients were obtained from routine report in all subdistricts in Bandung during the period of January 2008 to December $2011 .^{12-15}$ The incidence rate was calculated based on new cases of DHF patients who live in Bandung and were reported in Primary Health Centers and

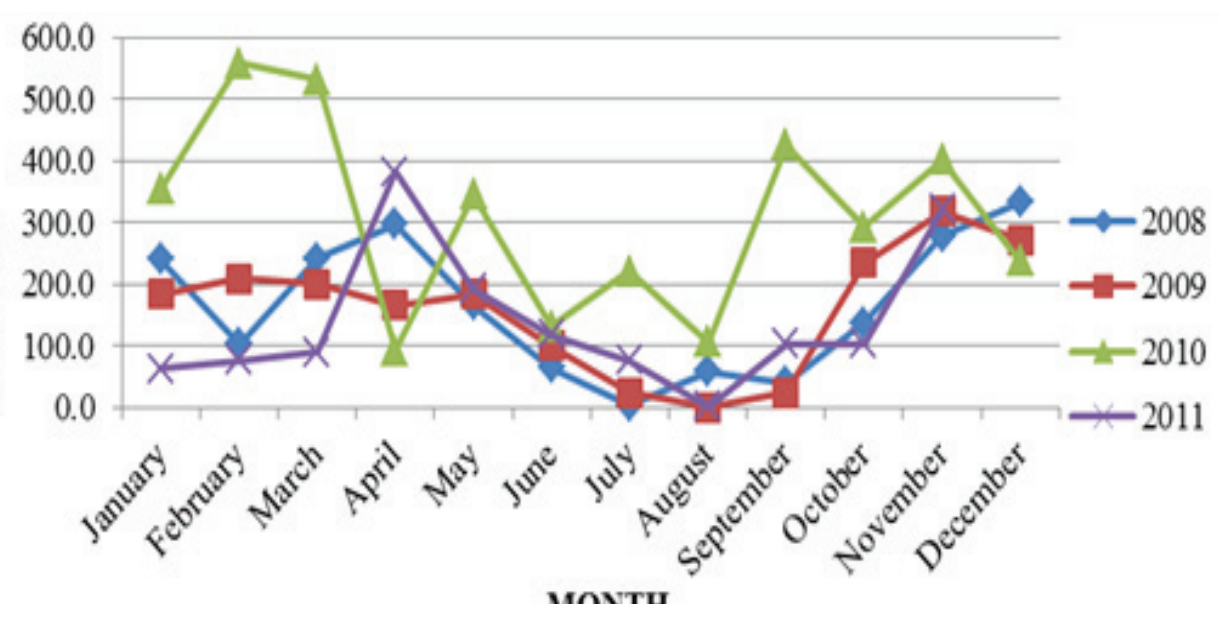

Figure 2 Average of Rainfall in Bandung during the Period of 2008 to 2011 


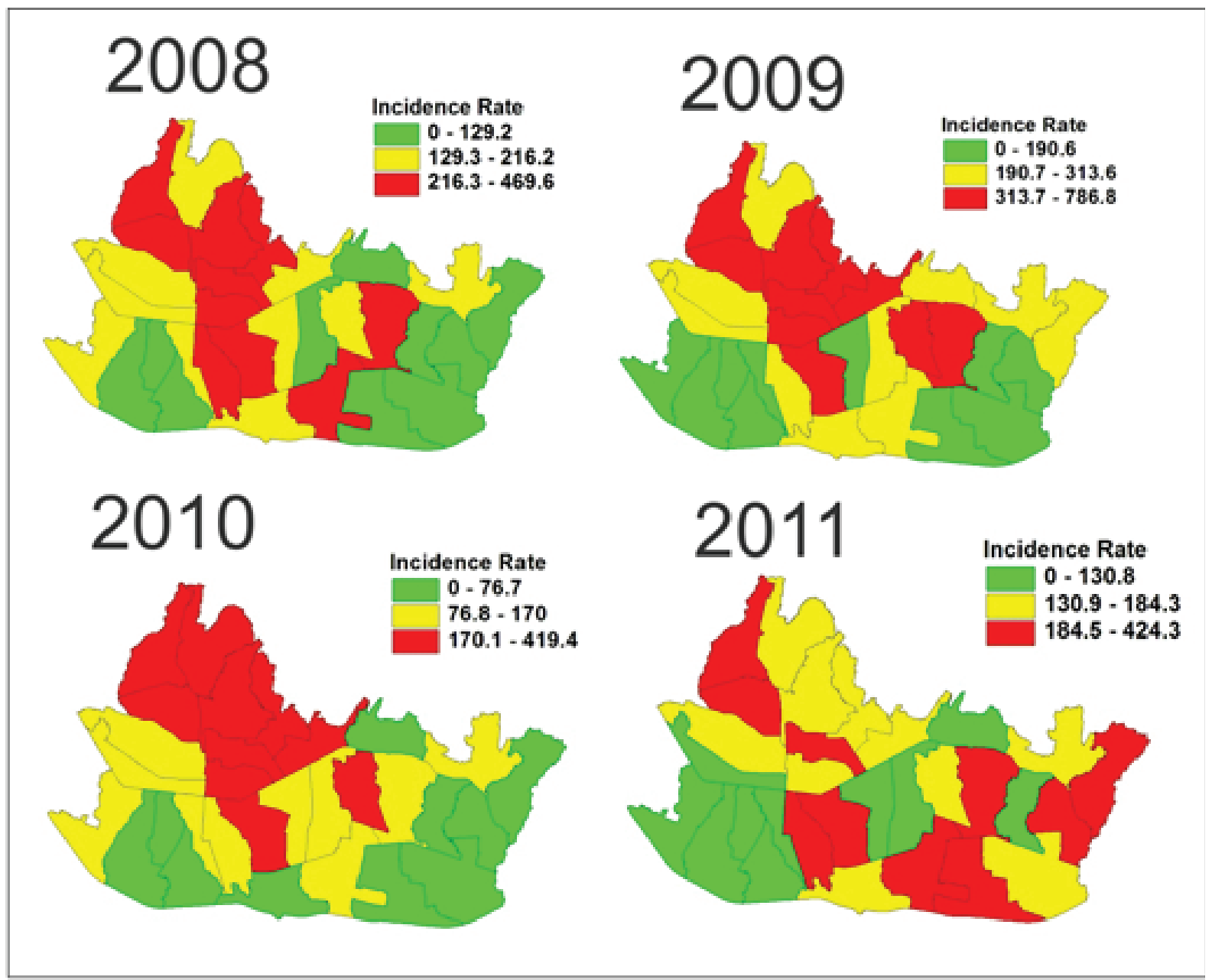

Figure 3 Mapping of DHF Incidence in Bandung during the Period of 2008 to 2011

Hospitals in Bandung.

Data were processed using computer and Arc View Geographic Information System 3.3 then presented as tables, graphics and mapping based on subdistrict. In the mapping of incidence rate distribution each year was divided into 3 areas. Red regions showed high incidence, yellow regions showed moderate incidence, while green regions indicated low incidence. The determination of this region was obtained from the calculation of the highest and lowest incidence from all subdistricts, then divided into 3 groups

\section{Results}

Incidence rate of DHF in Bandung was fluctuated during the period of 2008 to 2011 with the highest incidence occurred in 2009. Incidence rates of DHF during 2008 to 2011 (per 100.000 people) were 179, 277, 143 and

\section{2 , respectively.}

The highest incidence rate between 2008 to 2010 occurred in February, however in 2011 it occurred in January. The lowest incidence rate between 2008 to 2010 occurred in December, however in 2011 it occurred in January. The pattern of DHF incidence rate in Bandung increased from January to February and declined at the end of the year, (Figure 1).

The highest rainfall in Bandung during the period of 2008 to 2011 occurred in December, November, February and April, while the lowest rainfall occurred in July, August, April, August, respectively. The pattern of rainfall in 2008, 2009, and 2011 looked similar, which increased at the end of the year starting from October to December and declined in the midyear starts from June to September. However, in 2010, the rainfall patterns seemed different, where fluctuations occured throughout the year (Figure 2). 
Table 1 Implementation of Fogging in Bandung during the Period 2008 to 2011

\begin{tabular}{lcccc}
\hline & \multicolumn{2}{c}{ Highest } & \multicolumn{2}{c}{ Lowest } \\
\hline & Frequency & Subdistrict & Frequency & Subdistrict \\
2008 & 74 & Coblong & 8 & Cinambo \\
2009 & 133 & Coblong & 6 & Cinambo \\
2010 & 95 & Coblong & 9 & Andir \\
2011 & 25 & Coblong & 1 & Bandung Kulon \\
\hline
\end{tabular}

Distribution of DHF incidence in Bandung for the past 4 years showed a dynamic pattern. In the year 2008 to 2010, showed similar pattern, which the subdistricts with high incidence were exist in particular area, yet in the year 2011 the distribution dramatically change (Figure 3). From 30 subdistricts, there were 4 subdistricts that always be categorized as high incidence between 2008 to 2011 namely Sukajadi, Sukasari, Lengkong, and Bandung Wetan.

The highest frequency of fogging in 2008 to 2011 implemented in Coblong, where this subdistrict in the year of 2008 to 2010 was classified as high incidence area, although in the year of 2011, incidence rate in Coblong was categorized as moderate. The lowest and highest frequency of fogging in Bandung between 2008 to 2011 are showed in table 1 .

The highest incidence between 2008 to 2011 happened in subdistrict in Bandung Wetan in 2009 (IR: 786.6/100,000). During those periodes, high incidence rate neither followed by high population density nor high rainfall. Even so, high incidence rate in the year 2009 was followed by low larval free index (LFI) while in other years LFI were above 95\%, (Table 2)

\section{Discussions}

Incidence rate of DHF in Bandung between 2008 to 2011 experienced fluctuation every year. The highest incidence rate was found in year 2009 (IR: 276.6/100,000). This result shows that incidence rate in Bandung is much higher compared to incidence rate in Indonesia (IR: 66.83/100,000) according to data published by WHO. ${ }^{8}$

Surveillance and Data centre of Indonesian Ministry of Health stated that in the year of 2009, West Java Province was one of the high risk area for DHF (IR: 89.41/100,000). It showed that DHF incidence rate in Bandung which is the capital city of West Java was higher than the incidence rate of West Java Province. It probably was influenced by the ease of access to healthcare centers and also the higher level of knowledge about DHF compared to other regions that made the cases better recorded in Bandung. ${ }^{9}$

From the result of this study, DHF incidence rate in Bandung for each month between 2008 to 2011 has similar pattern which raise in certain months. The highest incidence of DHF between 2008 to 2010 happened in February, while in 2011 happened in January. The

Table 2 Relation of Rainfall, Population Density and DHF Prevention Program In Subdistrict With Highest Incidence

\begin{tabular}{|c|c|c|c|c|c|c|}
\hline & \multirow[b]{2}{*}{$\begin{array}{c}\text { Rainfall } \\
\text { (mm) }\end{array}$} & \multicolumn{4}{|c|}{ Highest Incidence } & \multirow[b]{2}{*}{$\begin{array}{l}\text { Frequency } \\
\text { of Fogging }\end{array}$} \\
\hline & & Sub-district & IR / 100.000 & $\begin{array}{c}\text { Population } \\
\text { density } \\
\text { (people/ } \\
\text { km2) }\end{array}$ & $\begin{array}{l}\text { Larval Free } \\
\text { Index (\%) }\end{array}$ & \\
\hline 2008 & 163.8 & Lengkong & 469.6 & 11,762 & 97.05 & 69 \\
\hline 2009 & 159.6 & $\begin{array}{l}\text { Bandung } \\
\text { Wetan }\end{array}$ & 786.6 & 9,523 & 93.18 & 54 \\
\hline 2010 & 307.8 & $\begin{array}{l}\text { Bandung } \\
\text { Wetan }\end{array}$ & 419.4 & 8,793 & 98.70 & 27 \\
\hline 2011 & 139 & Buah Batu & 424.3 & 11,768 & 97.00 & 24 \\
\hline
\end{tabular}

Althea Medical Journal. 2015;2(2) 
Incidence pattern shows the same pattern with the WHO where DHF incidence in Indonesia tends to raise in January and February. ${ }^{7}$ DHF incidence rate per month raise after months of highly rainfall. This study also shows similar pattern with the WHO SEARO, in which the research in Jakarta from 2002 to 2006 showed that DHF incidence rate raised after high rainfall with the peak of 9 weeks after. ${ }^{10}$

Mapping of DHF incidence from all subdistricts in Bandung between 2008 to 2011 emerges a dynamic pattern. This can happen because many factors can influence DHF case in a region, just as stated in DHF bulletin published by the Indonesian Ministry of Health where DHF can be affected by high population mobility and also adequate transportation in several regions. ${ }^{9}$

Fogging is one of the government prevention program to eliminate DHF. The highest frequency of fogging is implemented in high incidence subdistrict during the period of 2008 to 2010 . However, in the year 2011, fogging was not only implemented in high incidence subdistricts but also in area with larval free index less than 95\%. This is according to the procedure of fogging and indicates that government already has a great response. The success of community participation in DHF prevention program is indicated by LFI which is above 95\%.9 The average of LFI from all subdistricts in Bandung from 2008 to 2011 shows that it reached above $95 \%$ only in 2008 In 2010 , the average of larval free index reached the lowest point, nevertheless the incidence rate also reached the lowest point. This can happen because many factors can influence the event of DHF such as transportation facility and high mobility. Those factors allow the spread of DHF in living quarters, as reported from a study of DHF risk factor in Mojosongo village, Boyolali Regency, that the sedentary habit in the morning is not a risk factor of DHF., ${ }^{9,11}$

Indonesian Ministry of Health stated that population density can influence DHF case. ${ }^{9}$ However, this study shows that subdistricts with the highest incidence rate in Bandung during the period of 2008 to 2011 have population density below average of population density in Bandung.

There are limitations in this study, because it only describes DHF distribution with rainfall and population density. However, the association of those variables are not further analyzed and other factors which might influence DHF case is not explored. Data used in this study were secondary data and there was a lack of data especially in rainfall data in December 2011.

In conclusion, DHF incidence rate in Bandung between 2008 to 2011 is fluctuative with dynamic pattern, and highest incidence occurred in 2009. Incidence of DHF tends to be high in the months after highly rainfall (January and February) which then declines in the end of the year. DHF incidence rate distribution in every subdistricts in Bandung is not related to population density. The government prevention program of DHF already shows great response. However, public participation to prevent DHF with elimination of breeding sites still has not been optimized yet.

It is recommended that Bandung Health Office should increase the effort to prevent DHF especially in subdistricts with high incidence by increasing community empowerment in eliminating breeding sites of dengue vector especially before rainy season. That effort should not be only performed in households, but also in public facilities such as schools or offices. Cadre mentoring program is suggested to be conducted by Primary Healthcare Centers. Further study is needed to analyze other factors which might affect DHF incidence in Bandung.

\section{References}

1. WHO. Situation of dengue/dengue haemorrhagic fever in South-East Asia Region. 2007 [Cited 2012 March 20]. Available from: http://www.searo.who. int/en/Section10/Section332_1103.htm.

2. WHO. Disease: impact of dengue. [Cited 2012 March 20]. Available from: http:// www.who.int/csr/disease/dengue/ impact/en/

3. WHO. Situation of Dengue/Dengue Haemorrhagic Fever in South-East Asia Region. 2007. [Cited 2012 March 20]. Available from: http://209.61.208.233/ en/Section10/Section332_1098.htm

4. WHO. Reported Cases of DF/DHF in Selected Countries in SEA Region (19852005). 2007 [Cited 2012 March 20]. Available from: http://209.61.208.233/ en/Section10/Section332_1101.htm

5. Kemenkes RI. Waspada Demam Berdarah Dengue. Pusat Komunikasi Publik Sekretariat Jenderal Departemen Kesehatan. [Cited 2012 March 20]. Available from: http://www.depkes.go.id/ index.php/berita/press-release/439waspada-demam-berdarah-dengue.html. 
6. Health Research and Development Office, Ministry of Health RI. Riset Kesehatan Dasar Jakarta: Ministry of Health RI. 2nd ed. Jakarta: Health Research and Development Office, Ministry of Health RI; 2009.

7. Hauser K, Longo B, Jamerson F. Harrison's Principles of Internal Medicine. 16th ed. New York: Mc Graw-Hill; 2004. p. 1164.

8. WHO SEARO. Situation Update of Dengue in The SEA Region. WHO Library Cataloguing-in-Publication data. 2010 [Cited 2012 October 15]. Available from: http://209.61.208.233/LinkFiles/ Dengue_Dengue_update_SEA_2010.pdf

9. Pusat Data dan Surveilans Epidemiologi Kementerian Kesehatan Republik Indonesia. Demam berdarah dengue di Indonesia tahun 1968-2009. Buletin Jendela Epidemiologi. 2010;2:1-9 [Cited 2012 October 15]. Available from: http:// www.depkes.go.id/downloads/publikasi/ buletin/BULETIN\%20DBD.pdf

10. WHO. Trend of dengue case and CFR in
SEARO cCountries. 2007 [Cited 2012 March 20]. Available from: http://www. searo.who.int/en/Section10/Section332/ Section2277_11960.htm.

11. Azizah Gama T, Faizah Betty R. Analisis faktor risiko kejadian demam berdarah dengue di Desa Mojosongo Kabupaten Boyolali. Eksplanasi. 2010:5(2):1-9 [Cited 2012 October 20]. Available from: http:// www.kopertis6.or.id/journal/index.php/ eks/article/view/12/10

12. Bandung Health Office, West Java Province. Health Profile of Bandung 2008. Bandung: Bandung Health Office; 2009.

13. Bandung Health Office, West Java Province. Health Profile of Bandung 2009. Bandung: Bandung Health Office; 2010.

14. Bandung Health Office, West Java Province. Health Profile of Bandung 2010. Bandung: Bandung Health Office; 2011.

15. Bandung Health Office, West Java Province. Health Profile of Bandung. Bandung: Bandung Health Office; 2012. 